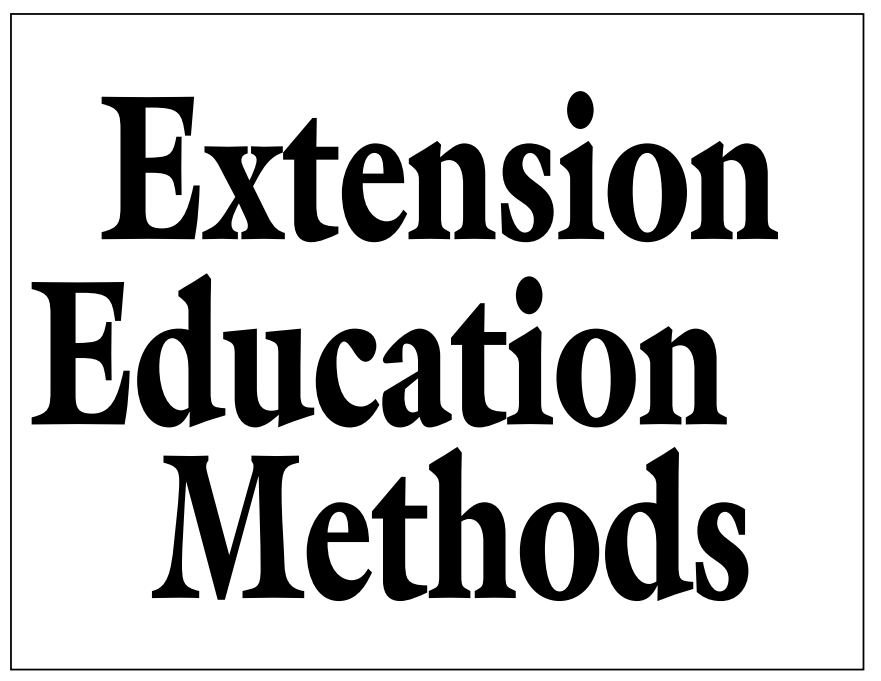

\section{Evaluating On-line Training Modules in the Oregon Master Gardener Program}

\author{
Ann Marie VanDerZanden ${ }^{1}$ and \\ Christopher Hilgert ${ }^{2}$
}

Adpitional IndeX words. on-line modules, evaluation tool, survey, computer based training, assessment, distance learning

SUmmary. In conjunction with two noncredit, on-line training modules for the Oregon Master Gardener Program, a team of educators and web designers developed an evaluation tool to help determine the effectiveness of these modules for training Master Gardeners. The evaluation tool includes questions on technical issues, organization and presentation of the module, navigation throughout the module, content and user satisfaction. Data collected from participants via the tool in 1999 on the basic botany module, highlighted areas that needed improvement including reducing the amount of on-screen reading (organization and presentation) and an inability of participants to access video clips and animations (user satisfaction). Overall, participants gave both modules high marks in each of the five categories. Major modifications made to the soils and fertilizers module in $\mathbf{2 0 0 0}$ were likely responsible for the improved organization/presentation rating (2.4 in 1999 to 1.9 in 2000 where $1=$ highly positive ranking; 5 = highly negative ranking) and the user satisfaction rating (2.5 in 1999 to 2.0 in 2000$)$. Both years the overall acceptability of the course was high $1.45(1=$ highly positive ranking; 5 = highly negative ranking) and $1.80,1999$ and 2000 respectively, and has encouraged the team to continue developing on-line training modules for the Oregon Master Gardener Program.

Department of Horticulture, Oregon State University, 4017 ALS Bldg., Corvallis OR 97331-7304.

${ }^{1}$ Associate professor and State Coordinator Oregon Master Gardener Program.

${ }^{2}$ Graduate research assistant.
$\mathrm{T}$ he Internet and modern technology have opened new doors for educational experiences that can meet the variable needs of millions of users. As an educational resource the Internet enables students to interact with instructors and subject matter experts around the world, and allows the flexibility to work and learn at times and in locations that fit their needs (Lippert et al., 1998; Tennessen et al., 1997).

While extension traditionally has delivered information in face-to-face meetings (Beaudin, 2000), it now has an opportunity to expand its educational outreach. By recognizing the evolving needs of local stakeholders and evaluating new tools available through the Internet, Extension's functionality and role in extended education can be enhanced (DeYoung et al., 1995; Tennessen et al., 1997). Examples of successful on-line program delivery within Extension include training sessions for Extension faculty, volunteers, volunteer managers, and county-based clientele (Beaudin, 2000; Lippert et al., 2000; Sherfey et al., 2000). Specifically, Lippert et al. (2000) reported success with this method of delivery as measured by increased post-test scores and with participants rating on-line training as effective as traditional teaching methods.

Our observations suggest on-line training modules are much different from traditional training tools and require a broad application of pedagogy. In many modules, accurate and well-organized content is combined with on-line resources such as off-site links, audio or video clips, email, and listserves. Ultimately, the module needs to have accurate content, and be visually appealing and user friendly. Although on-line education is becoming commonplace, and the literature does reflect some good examples of successful programs, Merisotis and Phipps (1999) noted more research is needed to better understand the effectiveness of this teaching method and if students learn and retain as much as via traditional classroom instruction. The evaluation tool discussed in this paper may be a useful means of addressing some of these questions.

\section{Materials and methods}

The Oregon Master Gardener program has grown steadily over the past 26 years. In 2001 over 850 new Master Gardeners received 48 to $66 \mathrm{~h}$ of initial training at 19 sites throughout Oregon. The logistics of training this many new volunteers annually, combined with the number of distant training locations, have facilitated the need to explore alternative training methods. In 1999 and 2000 a team of educators and web designers at Oregon State University developed two noncredit, on-line training modules for the Master Gardener Program. The 1999 module covered basic botany and the 2000 module covered soils and fertilizers.

To evaluate the effectiveness of the two modules, an evaluation tool was developed based on a matrix of questions for web site evaluation generated by Bakken and Armstrong (2000). In consultation with an evaluation specialist (M. Engle, personal communication), the research team selected relevant questions from the matrix and used them to evaluate the training modules. The evaluation tool (Fig. 1) was formatted into a Likert scale (Likert, 1932) and divided into four categories, each containing multiple questions, to evaluate technical issues (two questions), organization and presentation of the module (six questions), navigation throughout the module (six questions), and content 
Technical

\begin{tabular}{|l|l|l|l|}
\hline Works in all browsers. & || $\mid \begin{array}{l}\text { These pages need } \\
\text { specific browser. }\end{array}$ \\
\cline { 2 - 3 }
\end{tabular}

\section{Organization and Presentation}

\begin{tabular}{|l|l|l|l|}
\hline $\begin{array}{l}\text { The layout is clear and } \\
\text { easy to follow. }\end{array}$ & $|1| \begin{array}{l}\text { Layout is confusing } \\
\text { or inappropriate. }\end{array}$ \\
\hline
\end{tabular}

\section{Navigation}

\begin{tabular}{|l|l|l|}
\hline Easy to navigate through & || $\mid$ Difficult to navigate. \\
the pages. & \\
\hline
\end{tabular}

\section{Content}

\begin{tabular}{|l|l|l|}
\hline $\begin{array}{l}\text { Information relates to the } \\
\text { overall purpose. }\end{array}$ & $|1| \begin{array}{l}\text { No way to check } \\
\text { validity of information. }\end{array}$ \\
\cline { 2 - 3 }
\end{tabular}

User Satisfaction

Overall, the online course was acceptable.

\section{Strongly agree}

Fig. 1. Sample questions from each category of the on-line training module evaluation tool used with the soils and fertilizer, and basic botany modules of the Oregon Master Gardener Program. The complete evaluation tool is available at <http://www.osu.orst.edu/extension/mg> (VanDerZanden, 2001). Directions: Place an " $X$ " on the line next to each statement to indicate how much you agree or disagree with the statement. Place only one " $X$ " on each line.

(eight questions). An additional section on user satisfaction was included to discern if participants felt these modules could be a viable alternative for future Master Gardener trainings. This section contained seven questions in 1999 and five in 2000. The goal of the entire evaluation tool was to determine if the modules were effective teaching tools and if they provided a satisfactory learning experience for the Master Gardener trainees.

\section{Results and discussion}

Thirty-two Master Gardeners evaluated the 1999 basic botany module and 28 evaluated the 2000 soils and fertilizers module. The evaluation tool provided researchers with a student perspective reflecting the relevance of the information, layout, and the ease or difficulty of accessing and navigating through the modules. A synthesis of the of participants' comments provided valuable feedback on the modules and highlighted areas that needed improvement.

Overall, participants gave the two modules high marks in each of the five survey categories (Table 1). Two categories, organization and presentation, and user satisfaction, received the poorest ratings in 1999, and significant changes were made in these two areas during development of the 2000 module.

The 1999 module was heavily text based and required a substantial amount of on-screen reading. User comments noted this became tiresome and caused eye fatigue. Researchers modified the 2000 module format so it required significantly less on-screen reading, and this may account for the improved score in 2000. In 1999 the user satisfaction category had two questions related to the ability of users to access a video clip and two animations, and subsequently what value these added to the course. Participants gave these components low rankings, 4.1 and 4.0 respectively, suggesting they were unable to access these features and hence did not see any value in them. When compared to other questions in the user satisfaction category, it was obvious that this problem needed to be addressed (Table 2). We eliminated video clips and animations from the $2000 \mathrm{mod}-$ ule, and are currently conducting a survey to determine the types of hardware and software most often used by Master Gardeners with the goal of developing multimedia that is more compatible with users' equipment.

This evaluation tool may be useful to others who are developing on-line training modules. It can serve as a basic matrix of questions and additional questions related to specific features of a module can be included as needed to help educators and researchers evaluate the module. Online training may not be appropriate in every case, but it may greatly increase accessibility to extension training and certification programs that otherwise would not be available to place- and time-bound learners.

Table 1. Average score for each survey category from the evaluation tool used with the basic botany module in 1999 and the soils and fertilizers module in 2000 .

\begin{tabular}{lcc}
\hline $\begin{array}{l}\text { Survey } \\
\text { category }\end{array}$ & $\begin{array}{c}1999 \\
\mathbf{( n = 3 2 )}\end{array}$ & $\begin{array}{c}\mathbf{2 0 0 0} \\
(\mathbf{n}=\mathbf{2 8})\end{array}$ \\
\hline Technical (two questions) & $1.5^{\mathrm{z}}$ & 1.6 \\
Organization and presentation (six questions) & 2.4 & 1.9 \\
Navigation (six questions) & 1.8 \\
Content (eight questions) & 1.5 \\
User satisfaction (seven questions in 1999; five questions in 2000) & 2.5 & 1.6 \\
\hline
\end{tabular}

${ }^{\mathrm{z} E v a l u a t i o n}$ using a five-point Likert scale (Likert, 1932), where 1 = highly positive ranking and 5 = highly negative ranking. 
Table 2. User satisfaction category from the survey tool used with the basic botany module in 1999 and the soils and fertilizers module in 2000.

User satisfaction

questions

\section{9}

$(\mathbf{n}=39)$

Overall, was the online course acceptable to you?

Did the online course provide an adequate learning experience?

Is the convenience of taking a course online important to you?

Was technical support for the course adequate?

Through use of the communication tools (listserv, chatroom) included with the course, did you feel connected to other learners in the course?

Through use of the communication tools (email, chatroom) included with the course, did you feel connected to the course instructor?

The introductory video and animations on transpiration and pollentube growth worked on my system.

The introductory video and two animations enhanced the quality of the course Overall user satisfaction average $1.45^{\mathrm{z}}$

1.60

2.10

1.55

2.90

2.50

4.10

4.00

2.52
2000

$(\mathbf{n}=\mathbf{2 8})$

1.80

1.80

1.90

1.50

2.85

2.40

NA

NA

2.04

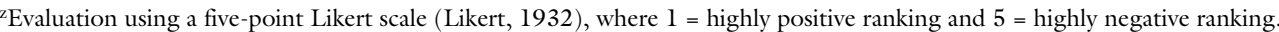

\section{Literature cited}

Bakken, C. and S. Armstrong. 2000. Web page evaluation criteria Challenge 2000, CTAP Region IV Technology Leadership Academy and the Institute for Research on Learning. 13 Dec. 2001. <http://www.uxl.eiu.edu/ cfmgb/web.htm>

Beaudin, B. 2000. Delivering short seminars and workshops to farmers and ranchers with low bandwidth on-line technologies. J. Ext. 38(5). 13 Dec. 2001. <http://www.joe.org/joe/ 2000october/rbl.html>

DeYoung, B., P. Harris, and L. Larsen. 1995. Virtual communities and university outreach. J. Ext. 33(1). 13 Dec. 2001. <http:// www.joe.org/joe/1995february/a5.html>

Likert, R. 1932. A technique for measurement of attitudes. Arch. Psychol. 140:15-20.

Lippert, R.M., O. Plank, J. Camberato, and J. Chastain. 1998. Regional extension in-service training via the internet. J. Ext. 36(1). 13 Dec. 2001. <http://www.joe.org/joe/1998february/ a3.html>
Lippert, R.M., O. Plank, and R. Radhakrishna. 2000. Beyond perception: a pretest and posttest evaluation of a regional internet extension in-service training. J. Ext. 38(2). 13 Dec. 2001. <http:/ /www.joe.org/joe/2000april/a2.html>

Merisotis, J.P. and R.A. Phipps. 1999. What's the difference? Outcomes of distance vs. traditional classroom-based learning. Change 13-17 May/June.

Sherfey, L.E.B., J. Hiller, N. Macduff, and N. Mack. 2000. Washington State University on-line volunteer management certification program. J. Ext. 38(4). 13 Dec. 2001. <http:// www.joe.org/joe/2000august/ttl.html>

Tennessen, D.J., S. PonTell, V. Romine, and S.W. Motheral. 1997. Opportunities for cooperative extension and local communities in the information age. J. Ext. 35(5). 13 Dec. 2001. <http:/ /www.joe.org/joe/1997october/comml.html>

VanDerZanden, A.M. 2001. Oregon Master Gardener Program. 13 Dec. 2001. <http://www.osu.orst.edu/extension/mg> 